\title{
New York to police air monitoring
}

Taking stock of New York City's air and water may soon be more difficult for researchers. A new bill from the administration of Mayor Michael Bloomberg would make it a misdemeanour to possess or use a chemical, biological or radiological detector without a permit issued by the city's police department.

The legislation, which would be the first of its kind in the United States, is designed to regulate a growing number of firms that sell environmental sensors to guard against terrorist attacks. But some say that its current language is too vague and would include thousands of privately held sensors used routinely to monitor the city's air and water quality.

"At best, it would just be adding a huge level of bureaucracy and expense," says environmental geochemist Steven Chillrud of the Lamont-Doherty Earth Observatory at Columbia University in New York. Chillrud, who has studied the health effects of steel particles in the city's subways as well as air quality after the 11 September 2001 attacks, is helping to lead a move against the bill along with colleagues.

Last year, the US Department of Homeland Security approached the city's police department to discuss regulating the sensors. Police say that introducing permit requirements would ensure the sensors' quality, reduce the potential for false alarms and establish a clear alerting process in case of positive results. "For public safety reasons we need to know who is using these devices," says Jason Post, the mayor's deputy press secretary.

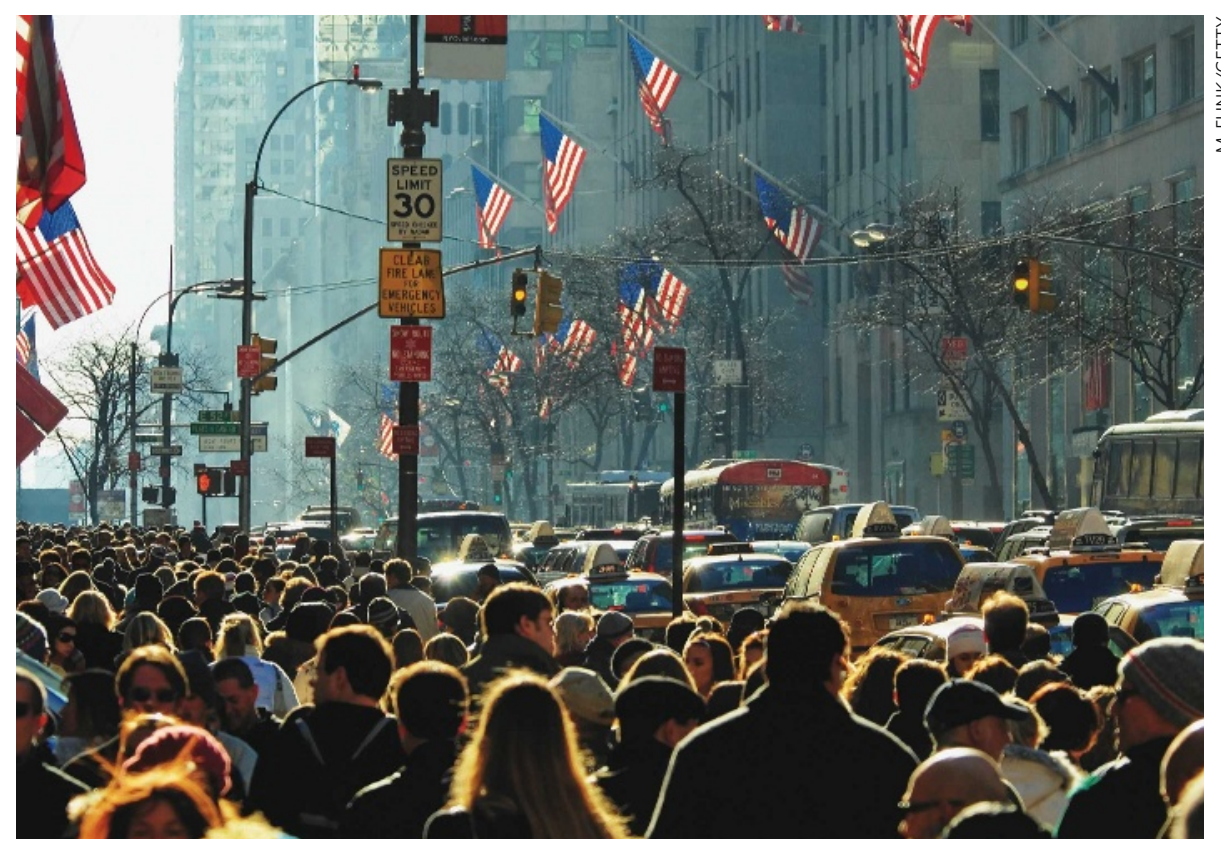

Change in the wind: monitoring the air on New York's Fifth Avenue may become illegal without a permit.

But the line between a detector that is specifically designed to pick up on an attack (see 'BioWatch to get second look'), and longstanding technology that may do it as a matter of course, is proving hard to define. The bill does not specify which types of detectors will require permits, nor does it exempt certain groups from permit requirements.

That flexibility, says Chillrud, means that the

\section{BioWatch to get second look}

As New York City considers permits for privately held biological sensors, the federal programme for detecting biological threats is due for a review. In spending bills approved late last year, Congress set aside $\$ 2$ million for the National Academy of Sciences to review the $\$ 77$ million BioWatch programme, which was set up by the Department of Homeland Security after the terrorist attacks of 11 September 2001.

The review has not yet started.

So far, the five-year-old

BioWatch programme has placed air-collection devices in more than 30 US cities.
These devices, which hold air samples for later analysis, are poised to be replaced by a next generation of automated boxes. Twenty-six of these new boxes, which have been in development since the start of the programme, will be piloted this year in two undisclosed cities at a cost of $\$ 5.8$ million.

Congress requested the review after hearing testimony last year from public-health advocates who say that the programme's budget should be invested instead in developing rapid diagnostics for hospitals, better disease reporting, and surveillance of public-health trends. But supporters of the programme say that none of these measures will mitigate the impacts of a large biological attack.

"The whole idea behind BioWatch is to detect the attack as soon as it can occur," says former Department of Homeland Security assistant secretary Penrose Albright, now the managing director of the Washington-based consulting firm Civitas Group. He says that models show that waiting for individuals to show up in the emergency room could potentially waste days and cost thousands of lives. R.C. bill "doesn't preclude someone years from now from taking advantage of this all-encompassing language".

Of particular concern is the potential to hinder the deployment of environmental monitors in emergencies or for independent analysis of other findings. Requiring permits, Chillrud says, could also impede routine activities such as borrowing equipment from colleagues.

"It's overbroad and imposes major limitations on community organizations, academic institutions and others concerned with monitoring the environment," adds Joel Shufro, director of the New York Committee for Occupational Safety and Health, which routinely conducts indoor air-quality tests.

Although public input was not sought before the legislation was drafted, last week the police department requested comments from researchers through Columbia University administrators. "There are some problems that exist with the bill that need to be rectified," says Peter F. Vallone Jr, chair of the council's publicsafety committee.

A revised draft of the bill, circulated late last week, included time-limits on the permitting process to prevent unnecessary delay. Final language for the bill may be decided on as early as mid-February, and the council plans at least one more public meeting to discuss it before it comes to a vote.

Rachel Courtland 